Journal of Bangladesh Academy of Sciences, Vol. 37, No. 2, 159-163, 2013

\title{
BIOENGINEERING APPROACH FOR SEWAGE SLUDGE DEGRADATION THROUGH AEROBIC THERMOPHILIC PROCESS
}

\author{
BIJAYA NANDA NAIK*, HARISON MASIH AND AJAYA SINGH \\ Dept. of Microbiology \& Fermentation Tech, School of Biotechnology \& Bio- \\ Engineering, SHIATS University, Allahabad, 211007, UP, India
}

\begin{abstract}
The aerobic thermophilic sewage sludge treatment process was studied at various bioreactor scales through modified bioengineering design approach. The effectiveness of the biological system was controlled by varying the process operating conditions of bioreactor to enhance microbial degradation efficiency. The inactivation of pathogen each promoted by increase of temperature, while the residual CFU was lowered by reducing the total solids content of sewage sludge. The optimum sludge degradation through aerobic thermophilic process occurred in temperature range of $58-62^{\circ} \mathrm{C}$ but temperature more than $60^{\circ} \mathrm{C}$ was suitable for hygienic inactivation. Dual digestion systems of an aerobic theromophilic treatment followed by anaerobic thermophilic stabilization stage shows greater treatment and efficiency in degrading the organic sludge constituting up to seventy per cent.
\end{abstract}

Key words: Sewage, Sludge, Aerobic, Thermophilic, Bioengineering, Wastewater

\section{INTRODUCTION}

In industrial communities an environmental problem such as the treatment and degradation of the increasing quantities of wastewater and sewage sludge requires the improvement of the existing technologies. Several types of process are commonly applied for sewage sludge treatment. Out of these, there is conventional anaerobic digestion of sludge ineffective for significant conversion of organic matters. Mohasen and Shojaosadati (2006) in their studies showed that thermophilic aerobic digestion of sludges have clear advantages over convetional mesophilic degradation. For this reason it is necessary to introduce bioengineering and biotechnological process which operate at elevated temperature such as the aerobic thermophilic process to degrade sludge.

Industrial, municipal and domestic wastewater contain organic and inorganic matter in suspended, colloidal and dissolved form. The concentration of wastewater depends on the original concentration of dissolved materials in the waste disposal and the use to which the water has been put. The presence of industrial waste in public sewers can substantially alter the nature of waste water. The stronger sewage will have a greater

*Corresponding author: <bnanda_n@yahoo.co.in>. 
proportion of putrescible compounds. The concentration of sewage or effluent depends on soluble and insoluble organic materials as bye-product of the sludge.

The main objective of the present research in nonconventional bioengineering approach for sewage sludge treatment is to achieve organic matter degradation and conversion, sludge quantity reduction, improvement of the physico-chemical characteristics of sewage sludge and inactivation of pathogenic microorganisms through treatment process where the degrading microorganisms use dissolved oxygen in the media.

\section{MATERIALS AND METHODS}

From the bioengineering and biotechnological point of view the aerobic sludge treatment process involves, the microorganisms and degradation biocatalysts, the process-bacteria mediate the bio-degradation process that occur and utilize the resultant product produced from lysis of the bed microbe and of process bacteria.

The active thermophilic microflora in aerobic thermophilic sludges is very homogenous in consisting nearly exclusively of the thermophilic bacilli of which more than $95 \%$ have been classified as type of Bacillus stereothermophilus. The strains of $E$. coli and B. stererothermophilus were identified, isolated from sludge, cultured for application as per method given in Bergey's Manual of Systematic Bacteriology (Buchanan and Gibson 2005). Mixed population of these isolated and cultured strains of bacteria from sludge were inoculated with one more strain of Bacillus steriothermophilus (ATCC-7953/NCIM-2235) to see the impact of these mixed population on degradation and conversion in pilot plant scale by maintaining diluted inoculant $10^{-1}$ to $10^{-4}$ cell ml $\mathrm{ml}^{-1}$ (Bomoi 1990).

Lab type bio-reactor used with different bioengineering process and designs for better degradation and improvement of treatment process. Repetitive batch mode was employed in all experiments with variable mean residence time. Several process variables were employed and aerobic thermophilic sludge treatment process was modified and improved design for regulated aeration and temperature treatment with hydraulic retention times, for fermentation and low energy consumption during mixing of sludge. Incubation temperature was maintained between 53 to $66^{\circ} \mathrm{C}$ during the process. The sludge samples were prepared for COD, total carbon, nitrogen, $\mathrm{pH}$ and for total and volatile solid.

Bioengineering process efficiency was evaluated by biochemical analysis to estimate organic sludge digestion and conversion. Change in volatile solids, COD, total organic carbon and production of ammonium concentration and aerobic conversion to biogas are all indicators to measure the effectiveness of the sludge treatment and degradation. This shows the effectiveness of present bio-engineering approach study. COD was measured 
with colorimetry according to standard methods (APHA 1985). Total organic solids and volatile suspended solids content of sludge samples were done by standard distillation method (APHA 1985). The mass balance for degradation was calculated at time to find sludge volume change.

In bioengineering approach, the combination of dual degradation systems of an aerobic thermophilic treatment followed by an anaerobic mesophilic stabilization stage were tried for better results of organic matter reduction or full stabilization of sludge.

\section{RESULTS AND DISCUSSION}

Improved design of bioreactor with regulated mixing aeration and temperature treatment the aerobic followed by anaerobic digestion of sewage sludge (Rich 1987, Lettiga et al. 1980). The effects of the sludge total solids content at specific temperature on the bacterial inactivation were investigated. The reduction in number and inactivation of pathogenic microorganisms in sewage sludge was observed. The CFU was reduced by inactivation rate coefficient $\left(\mathrm{K}_{1}\right.$ and $\left.\mathrm{K}_{2}\right)$ for microbes is $10^{3}-10^{4} \mathrm{ml}^{-1}$ in the first $4-5 \mathrm{~min}$ at temperatures $\geq 60^{\circ} \mathrm{C}$. The sludge total solids content influenced the residual colony forming units number. The thicker the sludge was, the higher was the residual cell concentration. At low total solids contents $(1.5 \%)$, the residual cell number was estimated after $30 \mathrm{~min}$ incubation at $60^{\circ} \mathrm{C}$ to be $10^{2} \mathrm{ml}^{-1}$. With thicker sludge higher residual CFUs were usually found (Bomoi 1990). In the present study total solids in sludge was $6.5 \%$ with observed residual number of $103 \mathrm{ml}-1$ (Table 1 ).

Table 1. Inactivation rate constant for Bacillus stereothermophilus strain at different temperature and different sludge total solids content.

\begin{tabular}{cccc}
\hline Temp. $\left({ }^{\circ} \mathrm{C}\right)$ & Total solids $(\%)$ & $\mathrm{K}_{1}\left(\mathrm{~min}^{-1}\right)$ & $\mathrm{K}_{2}\left(\mathrm{~min}^{-1}\right)$ \\
\hline 58 & 1.5 & -0.68 & -0.15 \\
60 & 1.5 & -0.20 & -0.04 \\
62 & 1.5 & -2.24 & -0.04 \\
58 & 6.5 & -1.12 & -0.08 \\
60 & 6.5 & -2.02 & -0.04 \\
62 & 6.5 & -2.17 & -0.04 \\
\hline
\end{tabular}

From the differences in the measured inactivation rate coefficient, it is concluded that this microorganism (ATCC-7953/NCIM-2235) is more heat sensitive than the Bacillus stereothermophilus and E. coli species collected from sewage sludge. E. colli strains were utilized for the studies of inactivation kinetic, during thermal sludge treatment (Ponti 1993). Studies of the organic and hydraulic load effects showed the mean adverse consequences on anaerobic thermophilic degradation of sludge (Angelidaki and Ahring 1993). 
The inactivation of pathogenic microorganisms is essentially a thermal process. The introduction of anaerobic treatment can be advantageous in regulating the fed organic matter content to the aerobic digester leads to pathogens inactivation during sludge digestion. The inactivation of pathogenic microorganisms was essentially a thermal treatment process. Low total solid content in sewage sludge assured recovery of lower viable cell densities after the thermal treatment to improve the plant efficiency of sludge treatment process in a waste-water technical plant. Different operating process through bioengineering design approach for sludge degradation with simultaneous pathogens inactivation and sludge stabilization is novel study. Significantly the reduction in total organic solid is $0.5-0.6 \mathrm{~g} / \mathrm{l}$ and at the rate $1.5-6.5 \%$, the reduction in volatile suspended solid is $29.7 \%$ less at five days fermentation with 48 hrs retention time. Further combination of dual digestion systems consists of an aerobic thermophilic treatment followed by an anaerobic mesophilic stabilization stage after greater treatment efficiency up to $70 \%$. Thus the present study revealed that single process solution to sludge treatment need modification for successive dual approaches with hygienization, longer incubation times and high total solids content for wastewater treatment plant.

\section{CONCLUSION}

The aim of the present bioengineering approach was to improve the process efficiency at pilot plant scale in order to give reasonable solutions for operating wastewater technical plant in the field. The approach is effective sludge volume reduction with satisfactory inactivation of potential pathogens. Here operation costs will vary according to mean residence time and volume change frequency with high degradability and reduction in total organic solids. Thus dual digestion systems using anaerobic and aerobic thermophilic process with bioengineering processes design and improved operating condition will be a novel approach for treatment of different waste source with organic contents for resource recovery and safe disposal.

\section{ACKNOWLEDGEMENTS}

Authors thank Prof. (Dr.) R. Lawrence, Head, Dept. of Microbiology and Fermentation Technology; Prof. (Dr.) B. P. Masih, Dean, School of Biotechnology and Bioengineering, SHIATS University, Allahabad, U. P. India for extending facilities to work and reviewing the manuscript.

\section{REFERENCES}

Angelidaki, I and B. K. Ahring. 1993. Thermophilic anaerobic digestion of livestock waste; the effect of ammonia. Appl. Microbial Bitechnol. 38: 560-564.

APHA. 1985. Standard methods for the examination of water and wastewater (16 ${ }^{\text {th }}$ ed.) American Public Health Association, Washington, D. C. USA. pp. 516. 
Bomoi, M. 1990. Bioprocess development for aerobic thermophilic sludge treatment, Diss. ETH, Zurich, No. 9159.

Buchanan, R. E. and N. E. Gibson. (eds). 2005. Bergey's Manual of Determinative Bacteriology. William and Wilkins Company, Baltimore, USA. pp. 415.

Lettiga, G., A. M. Vonetsen, S. M.Hobma, W. Dezeex and A. Klapwijk. 1980. Use of up-flow. Sludge blankets (UASB) reactor concept for biological wastewater treatment, Biotechnol Bioengineering 22: 699-734.

Mohasen, N. and S. A. Shojaosadati. 2006. Thermophilic aerobic digestion of activated sludge; reduction of solids and pathogen microorganisms. Iran. J. Chem. Chem. Engg. 25(1): 67-71.

Ponti, C. 1993. Improvement of aerobic thermophilic sludge treatment at pilot plant scale. Diss. Swis, Federal Institute of Technology. Zurich, No. 10504.

Rich, L. G. 1987 Rational design of aerobic digestion systems. J. Envn. Engg, 113: 499-515.

(Received revised manuscript on 10 July, 2012) 